\title{
SPIRIT CHRISTOLOGY: LACTANTIUS AND HIS SOURCES
}

\author{
PAUL McGUCKIN \\ La Sainte Union College, Southampton, SO9 $5 H B$
}

Lactantius conceives the pre-existent Christ as the first-born spirit of God, a holy spirit from the supreme spirit of the Deity. ${ }^{1}$ Analogously the angels are spirits of God in so far as they too derive their origin from the Deity and share a spiritual nature. ${ }^{2}$ In this context the description 'spirit of God' would not constitute per se a divine title; it would rather signify a substantive being ${ }^{3}$ that participated in the spiritual nature of God, as opposed to a physical type of creaturehood. When Lactantius wishes to distinguish the Son who is God's spirit from the angels who are similarly God's spirits he always specifies the formulae; so he calls the Son either incorruptibilem spiritum ${ }^{4}$ or spiritum, qui esset virtutibus patris dei praeditus. ${ }^{5}$ Such a precise specification is always required since the concept of 'holy spirit' can be equally applied to the Father, the Son or the angels. The clearest differentiation of the Sonspirit from the angel-spirits occurs in Lactantius's adaptation of Tertullian's Logos theology where the Son is defined as the only communicative spirit of God, the Word, or vocal spirit, ${ }^{6}$ who fulfils the role of revelation. ${ }^{7}$

1 Divinae Institutiones (hereafter DI) II, 8,3: Deus ... produxit similem sui spiritum, qui esset virtutibus patris dei praeditus; DI IV, 6,1: Deus ... sanctum et incorrup tibilem spiritum genuit, quem filium nuncuparet.

2 Epit. 37.3: ex omnibus angelis, quos idem deus de suis spiritibus figuravit ... DI IV, 8,6: sed tamen sanctae litterae docent, in quibus cautum est illum dei filium dei esse sermonem itemque ceteros angelos dei spiritus esse. Cf. V. Loi, Lattanzio (Zürich, 1970), pp.176-83: 'spiritus quale sostanza celeste degli angeli'.

3 DI IV, 8,i0: nostri spiritus dissolubiles sunt, quia mortales sumus, dei autem spiritus et uiuunt et manent et sentiunt, quia ipse immortalis est et sensus ac uitae dator. nostrae uoces licet aurae misceantur atque uanescant, tamen plerumque permanent litteris conprehensae; quanto magis dei uocem credendum est et manere in aeternum et sensu ac uirtute comitari quam de deo patre tamquam riuus de fonte traduxerit!

4 DI IV, 6,1. The incorruptibilis is applied as a divine epithet - one in which the angcls evidently do not share, because he elsewhere teaches their sexual fall from grace (DI II, 14, 1-3).

5 DI II, 8,3. See also Epit. 37,3: solus in consortium summae potestatis adscitus est, solus deus nuncupatus.

6 DI IV, 8.7-9, c.g.: procedentem de ore suo vocalem spiritum, quem non utero, sed mente conceperat ...

7 DI IV , 8.6: sermo est spiritus cum voce aliquid significante prolatus. Cf. Tertullian, 
Lactantius's terminology, then, leads to a pneumatological doctrine that does not articulate a threefold, Trinitarian, structure of the Deity and which can therefore be classed as pre-Nicene binitarianism. The functions normally attributed to the person of the Holy Ghost, ${ }^{8}$ especially after Constantinople in 381 , are in Lactantius attributed either to the Son or to God himself, and he consequently appears to have no conception of any third spirit who can be called 'God'. Jerome twice complains of Lactantius's pneumatology on the grounds that he attributes the title 'holy spirit' indiscriminately to either the Father or the Son. ${ }^{10}$ This archaic pneumatology, which truly reflects the flexible language of the scriptures rather than being a sign of inperitia scripturarum, was no longer tolerated after the Council of Constantinople, and may well explain why the corpus of Lactantius's letters was 'lost' in antiquity. Jerome's reference is already an apologia to retain the DI for its apologetic merits irrespective of its heterodox pneumatology.

Jerome's interpretation that Lactantius's doctrine of the Holy Spirit rendered it an impersonal spirit of divine sanctification, would appear to be reliable. ${ }^{11}$ Such a binitarian doctrine, however, is not a theological aberration on the part of Lactantius. It represents a longstanding western tradition, more widespread than has often been imagined. ${ }^{12}$ The only oddity

Adv. Prax. 7,6: Novatian, De Trin. 30,183. Also A. Orbe, Hacio la primera teología de la procesión del Verbo, Estudios Valentinianos I,I (Rome, 1958), p.451; ibid. 1,2, pp.534, 540-54; V. Loi, Lattanzio ( $\mathrm{n} .1$ above), p.169.

8 Used personalistically, to avoid the evident confusion that can arise between 'spirit of God' and 'Spirit of God' or 'a holy spirit' and 'the Holy Spirit'. When 'Holy Spirit' is used personalistically to designate the third member of the Trinity, as wholly distinct from Christ, then the term will be italicized.

9 Jerome, Comm. in Ep. ad Galat., II,4: ... multi per inperitiam scripturarum, quod et Firmianus in octavo ad Demetrianum epistularum libro facit, adserunt spiritum sanctum saepe patrem, saepe filium nominari (PL 26, 399C).

10 Jerome, ibid., and Epist. 84,7: et apostolus praecepit: omnia legentes, quae bona sunt retinentes. Lactantius in libris suis et maxime in epistulis ad Demetrianum spiritus sancti negat omnino substantiam et errore Judaico dicit eum ad patrem referri vel ad filium et sanctificationem utriusque personae sub eius nomine demonstrari. quis mihi interdicere potest ne legam Institutionum eius libros, quibus contra gentes scripsit fortissime, quia superior sen ten tia detestanda est? (CSEL L 5, p.128).

11 Lactantius follows the Old Latin scriptural tradition of Christ's baptism which inserts the version of Ps 2:7, 'today I have begotten you', into the account of the Father's words to Christ - in order to stress the spiritual rebirth attendant on baptism, and to explain the Holy Spirit terms of sanctification rather than as the third person of the Trinity' (R.M. Ogilvie, The Library of Lactantius [Oxford, 1978], p.104); cf. A. Orbe, Hacia la primera teologia (n.7 above), 1,2, pp.542ff. See also N. Hock, $A$ Spirit Christology, Th 75 (1972), 226-32; P. Rosato, 'Spirit Christology: Ambiguity and Promise', TS 38 (1977), pp.423-49.

$12 \mathrm{Cf}$. B. Sturder, 'La Sotériologic de Lactance', in Lactance et son Temps, ed. J. Fontaine and M. Perrin (Paris, 1978), pp.270-1: 'le binitarisme, avant les discussions sur la divinité de l'Esprit Saint (avant 360), est un phénomène beaucoup plus étendu qu'on ne le pense, surtout dans la théologie latine. Ainsi constatons-nous que la théologie 
is the late date at which it appears, but even here it is typical of Lactantius to retain archaic theological strands, for he always looks back to the Church of the second-century apologists rather than forward to the Church of the post-Nicene fathers. In addition, Lactantius is not the last representative of the binitarian strand, for it can be discerned even into the early writings of Hilary ${ }^{13}$ and, perhaps even more interestingly, the creed of the Council of Sardica (343), which shows a clear conception that it was the Holy Spirit who assumed flesh of the virgin Mary.

This council, led by Hosius of Cordoba, was composed wholly of western bishops, and reflects the typical western concern with the divine unity rather than the plurality, not only in its credal Spirit Christology ${ }^{14}$ but also in its disciplinary decision acquitting Marcellus of Ancyra of all charges of heresy. Indeed, the whole terminology of the pneumatological question was only given precision by the debates on the personal deity of the Holy Spirit which postdated Lactantius by fifty years. Until this time the whole momentum of dogmatic development and formulation was supplied by scriptural exegesis. Christology advanced freely because a wealth of Old Testament proof texts could be found to elucidate the relationships of the Son and the Father, but few Old Testament testimonia could be similarly used to demonstrate the nature of a third divine spirit, and this goes a long way in explaining the slowness of pre-Nicene pneumatological development. ${ }^{15}$ Even the pre-Nicene Latin writers who did so much to fix the terms of a trinitarian theology,

d'Hilaire, à la différence de la théologie d'Athanase après 360 , est pratiquement binitariste.' Cf. also A. Orbe, Hacia la primera teologia (n.7 above), 1,2, p.553: 'la teología binitaria del autor de las Institutiones Divinae se avenia mal a recoger un elemento, probablemente tradicional, que aparece ya en S. Irenco y Tertulliano'. For a demonstration of the existence of such a spirit christology and its traditional respectability, cf. M. Simonetti. Note di Cristologia pneumatica, Aug. 12 (1972), pp.201-32; F. Loofs, 'Christologie' in RE IV, pp.26-7; H.A. Wolfson, The Philosophy of the Church Fathers (Cambridge, Mzss., 1964), pp.183-91, who cites all the patristic texts in which logos is equated with spiritus; also J. Barbel, Christos Angelos (Bonn, 1941), pp.188-92.

13 Hilary, Comm. in Matt. 3.1-3, 33.6. Cf. F. Loofs, 'Hilarius von Poitiers' in RE VIII, p.59; M. Simonetti, 'Note sul commento a Matteo di Hilario di Poitiers', VetChr I (1964), pp.57-8; P. Smulders, La Doctrine trinitaire de $S$. Hilaire de Poitiers (Rome, 1944), pp.84-8.

14 Mansi VI, col I216 D. (Gk text ibid. III, col.89): credimus et suscipimus paracly tum spiritum sanctum, quem nobis ipse dominus promisit et misit. et hunc credimus missum. et is passus non est, sed homo, quem induit, quem adsumpsit ex Maria virgine, qui potuit pati, quoniam homo mortalis, deus autem inmortalis. This view is essentially the theological tradition to which Pope Callistus held, and which is attacked by Novatian in the De Trin. 9,12.17. With regard to the Holy Spirit becoming incarnate of the Virgin, cf. J.N.D. Kelly, Early Christian Doctrines (London, 1958), p.144.

15 For example, for Justin the Old Testament 'Wisdom' was the Son. For Theophilus it refers to the Spirit. For Athanasius in the Festal Letters it denotes the Son, whereas in his Epistle to Serapion it refers to the Spirit. Cf. R.P.C. Hanson, 'Biblical Exegesis in the Early Church', in Cambridge History of the Bible I, pp.412-53, esp. pp.422-3. 
Tertullian and Novatian, are fundamentally motivated by a defence of the divine monarchy. Novatian's work De Trinitate was only given such a title in later ages and in fact he teachers very little on the Spirit in comparison to the extensive way he elucidates the relationship of the Father and the Son. ${ }^{16}$

Tertullian witnesses to this tradition of Spirit Christology which could use the terms 'spirit of God' and 'word of God' as interchangeable designations. He shows this in the Adv. Praxean, ${ }^{17}$ the De Oratione, ${ }^{18}$ the Apologeticus ${ }^{19}$ and the $A d v$. Marcionem $(4,18)$. But where Tertullian advances on the tradition, articulating the personal subsistence of the Holy Spirit as a third gradus of the one divine nature (Adv. Prax. 25), Lactantius makes no such advance.

So it is that the DI equates the $\operatorname{Logos}^{20}$ with the Spiritus Dei:

Even the philosophers had knowledge of this divine speech (sermo) for Zeno talks of the Logos as the arranger of natural reality and the maker of the universe ... for it is the spirit of God, though he called it the 'soul of Jupiter'. And Trismegistus ... often described the power and majesty of the word (verbum) as our former example illustrated where he admits that there is a certain holy and ineffable speech (sermo) that is beyond the power of man's expression. ${ }^{21}$

And Lactantius, along with Tertullian, and the almost unanimous tradition of the early Church, interprets the 'holy spirit' and 'power of the Most High' which comes upon the virgin Mary at the annunciation as a reference to the

16 Novatian, De Trin. 29, text ed. H. Weyer (Düsseldorf, 1962); cf. Editor's notes, p.182f: 'Even Novatian does not expressly call the spirit God'. See also H.B. Swete, The Holy Spirit in the Ancient Church (London, 1912), pp.107-9, and A. d'Ales, Novatien: étude sur la théologie romaine au milieu du troisieme siecle (Paris, 1925), pp.117-20.

17 Adv. Prax. 26.4: dicens autem spiritus dei, etsi spiritus dei deus, tamen non directo deum nominans, portionem totius intelligi voluit, quae cessura erat in filii nomen. hic spiritus dei idem erit sermo ... ita et hic sermonem quoque agnoscimus in nomine spiritus.

18 De Orat. 1,1: dei spiritus et dei sermo et dei ratio, sermo rationis, et ratio sermonis et spiritus utriusque, Iesus Christus dominus noster.

$19 \mathrm{Apol}$. 21: et nos etiam sermoni atque rationi itemque virtuti, per quae omnia molitum deum ediximus, propriam substantiam spiritum inscribimus. Ibid. (on Christ as a ray from the sun of God's deity): ita de spiritu spiritus, et de deo deus modulo alterum, non numero, gradu, non statu fecit, et a matrice non recessit, sed excessit.

20 DI IV , 9,1, on Logos as the speech, reason, voice and wisdom of God: 'Sed melius Graeci logon dicunt quam nos uerbum siue sermonem: logos enim et sermonem significat et rationem, quia ille est et uox et sapientia dei.

21 DI IV, 9.2-3: hunc sermonem divinum ne philosophi quidem ignoraverunt, siquidem Zenon rerum naturae dispositorem atque opificem universitatis logon praedicat ... est enim spiritus dei quem ille animum lovis nominavit. nam Trismegistus ... virtutem maiestatemque verbi saepe descripsit, sicut declarat superius illut exemplum, quo fatc tur esse ineffabilem quendam sanctumque sermonem, cuius enarratio modum hominis excedat. 
pre-existent Son, not a distinct 'Holy Ghost'.22 Similarly the spirit of God ${ }^{\mathbf{2 3}}$ who is the agent of prophetic inspiration is one and the same as the Son. ${ }^{24}$ For Lactantius it is this spirit of God who suffers the very torments he himself had foretold through the person of David in Psalm 21 (22). ${ }^{25}$

Lactantius's Christology is according to the classical Pauline SpiritusCaro formula, ${ }^{26}$ and in this context the 'holy spirit' which Jesus breathes into the disciples after the resurrection ${ }^{27}$ is evidently not a distinct hypostasis, but refers to the divine power of spirit possessed by the holy flesh of Christ whereby he was able to perform miracles during his earthly ministry. ${ }^{28}$ It is this divine power which naturally belongs to him that Christ communicates to his apostles as a resurrection grace.

The inarticulated state of Lactantius's pneumatology has frequently been explained on the basis of theological incompetence, or isolation from the mainstream of Christian thought. ${ }^{29}$ Accusations of theological incompetence, however, are usually merely ways of avoiding critical investigation of the subject by proscribing a writer from the outset, a type of patristics that was all too common in the earlier part of the century. And in addition, although Lactantius's theology appears strange in many aspects, all his treatments can be shown to be rooted in longstanding ecclesiastical traditions, and in almost every case his 'oddity' consists only in his preservation of archaic theological

22 DI IV, 12.1: Descendens itaque de caelo sanctus ille spiritus dei sanctam uirginem cuius utero se insinuaret elegit. at illa diuino spiritu hausto repleta concepit et sine ullo adtactu uiri repente uirginalis uterus intumuit. Similarly Ignatius, Magn. 15,2; Hippolytus, C. Noet. 16,4; Justin, Trypho, 100 and 1 Apol. 33; Clement of Alexandria, Poed. II, 19,4: Theophilus, Ad. Aut. II, 10; Irenaeus, $A d v$. H. V,1,3.; Tertullian, Adv. Prax. 26, 3-4; Hilary, De Trin. 2,26 [based on Rom 8:9; spiritus dei - spiritus Christi.]

23 This force of inspiration is logically equated with the Logos who as the 'vocal spirit' is pre-eminently the revealer. Lactantius's terms are 'holy spirit' (DI IV, 11,1) and more frequently 'divine spirit' (DI IV, 5,5; V 9,6; VI 1,1; VII 24,9).

24 DI IV, 14,15: quomodo autem et cum quibus mandatis a deo mitteretur in terram, declarauit spiritus dei per prophetam docens futurum ut cum uoluntatem summi patris fideliter et constanter inplesset, acciperet iudicium atque imperium sempiternum.

25 DI IV, 18,31: quae utique propheta non de se locutus est. fuit enim rex et numquam illa perpessus est, sed spiritus dei per eum loquebatur, qui fuerat illa passurus post annos mille et quinquaginta.

26 Rom 1:3-4. Cf. R. Cantalamessa, La primitiva esegesi cristologica di Romani 1 , 3-4 e Luca 1,35, RSLR 2 (1966), pp.69-80.

27 cp. Epit. 42-3: inspiravit in eos spiritum sanctum ac dedit eis potestatem mirabilia faciendi ut in salutem hominum tam factis quam verbis operarentur. The final phrase, 'deeds as well as words', relates the apostolic teaching to the teaching ministry of Christ. Lactantius not only interprets Christ's miracles as symbols of the magisterium (DI IV, $26,1-16$ ), but specifically describes it as a perfect teaching in 'words and deeds' (DI IV, 23-4, 24), esp. 4.24-19b.

28 Cf. DI IV, 26,11: non exigua inmortalis potentiae opera.

29 'His knowledge of Christian doctrine and literature was defective' (B. Altaner, Patrology, E.T., p.208) 'Everything Tertullian and Novatian had achieved for a systematic teaching on the Trinity is forgotten by Lactantius'. (H. Von Campenhausen, The Fathers of the Latin Church, E.T., p.75). 
forms, rather than an incompetent or heterodox invention of new. As to the question of a supposed isolation from mainstream theological circles accounting for the Lactantian pneumatology, the picture is far from clear, and no definite consensus yet exists among Lactantian commentators. Two facts, however, would argue against such a hypothesis. In the first place Lactantius uses a respectably wide range of Latin Fathers in his work; all his predecessors are mentioned honourably with the exception of Arnobius, whom he probably does not know. He uses their works for the most part in the manner of the professional rhetor searching for a 'bon mot' rather than entering into any serious dialogue with them; but then again, this was standard apologetical procedure, and a sufficient number of indications exist to show that Tertullian had undoubtedly influenced his theological understanding. In the second place, his skilful exegesis (far more widespread and significant in his work than was realized by the early Lactantian commentators $)^{30}$ argues eloquently that here is a man who has read and pondered deeply for many years before beginning to compose his own theological apologia. The depth of his scriptural knowledge would suggest that he was already a Christian in Numidia before leaving for Nicomedia, the eastern capital, on the summons of Diocletian. His final destination was Trier, in the Gallic province of Constantine, thus making him one of the few truly international pre-Nicene fathers, having personal experience of church life throughout almost the whole extent of the Empire.

In his exegesis it is clear that the Pauline letters and Hebrews have particularly influenced his thought and terminology. Nonetheless he also has some very esoteric sources: he is the only western Father, for example, to cite the Odes of Solomon ${ }^{31}$ and he is also much impressed by the "holy Sibyls'. Both types of literature would be very much at home in the very type of primitive Judaeo-Christian communities where a spirit christology would be likely to flourish. The thought that Lactantius might have had some kind of theological link with such communities, although alluring, is certainly insubstantial, for he uses the Sibylline oracles sparingly, mainly for apocalyptic statements that are remarkably sober; and even then, one suspects, not because of their Jewish roots (of which he is evidently unaware) but because he thinks they will have some historical appeal to the class of Roman literati to whom he addresses his work. He quotes the Odes of Solomon (Ode 19,6) simply as a demonstration that the virginal birth of

30 For example, the works of R. Pichon, Lactance (Paris, 1901) and P. Monceaux, Histoire littéraire de l'Afrique Chrétienne, vol. 3 (Paris, 1905; repr. Brussels, 1966). For the modern reversal of their judgement see P. Monat, Lactance: Institutions Divines $V$ (SC 204, 1973), p.44; idem, 'La Présentation d'un dossier biblique par Lactance', in Lactance et son Temps (n.12 above), pp.273-91: P. McGuckin, Researches into the DI of Lactantius (Diss. Durham, 1980), pp.141-216.

31 DI IV, 12,3, citing Ode 19,6. Cf. P. McGuckin, Researches, pp.135-40. 
Christ had been foretold centuries beforehand. It must be admitted that he does not have a wide range of texts to draw on in support of the notion: he first adduces the usual verse of Isaiah (7:14), followed by the citation of 'Solomon', which he clearly regards as a piece of canonical scripture on a level with the Isaian material, and he then adds in support a third rather peculiar proof drawn from Virgil's Georgics, to the effect that such a spiritual conception could be compared to the supposed impregnation of mares on windy days! ${ }^{32}$ There is no profound theological indebtedness hidden behind this sort of material. But Lactantius's choice of proof matter taken from the Scriptures does witness unmistakably to his dependence on some kind of manual of Testimonia, analogous to Cyprian's Ad Quirinum but circulating only in the eastern Church - the so-called 'non-Cyprianic bible source'. His judicious insertion of verses from this eastern source manual, interrupting the normal sequence of the Cyprianic manual as followed in the DI, serves to prove further that the esoteric sources that do exist in his work have merely a utilitarian value for him; and thus one cannot safely argue any connection between Lactantius's theology and the original theological schools in which these more exotic pseudepigrapha flourished. He is simply using a handbook of testimonies that he has discovered at Nicomedia to supplement his more normal reliance on Cyprian. There is no valid evidence to substantiate A. Wlosok's thesis that the use of this manual marks out Lactantius as a crypto-gnostic. ${ }^{33}$

A possible explanation of his reserved pneumatology which has rarely been considered to date is the wholly apologetic nature of the Institutes; for it is quite feasible that such a protocatechesis as the DI might be content with leading the pagan mind to a belief in one God and his Son, leaving further instruction for the catechumenate proper. In this case the initiation into the doctrine of the spirit would be given in the episcopal preparations for baptism - when the neophyte would also be initiated into the sacramental mysteries - none of which are developed in the DI. Neville Clarke, in a recent issue of this journal, ${ }^{34}$ has already demonstrated the importance of the liturgical rites in articulating for the Church the sanctificatory role of the Spirit as a distinct hypostasis within the economy of the Son's salvific work. The preservation of mystical secrets, a theme which Lactantius touches on more than once, is a likely reason for his almost total silence with regard to eucharistic practice in the Church of his day. Neville Clarke, in any case,

32 DI IV, 12,3ft.: et sacpe sine ullis conjugiis vento gravidae, mirabile dictu (Georgics 3,274). Lactantius has in mind, of course, the word play on ventus-spiritus.

33 See A. Wlosok, 'Zur Bedeutung der nicht-Cyprianischen Bibelzitate bei Laktanz', Studia Patristica 4 (T.U. 79, 1961), pp.234-50. See also P. McGuckin, 'The Non-Cyprianic Scripture Texts in Lactantius' DI', VigChr 36 (1982), pp.145-63.

34 N. Clarke, 'Spirit Christology in the light of Eucharistic Theology; HeyJ (1982), pp. $270-84$, esp. p. 272. 
has already demonstrated that even where we do possess an anaphora roughly contemporaneous with Lactantius, that of Serapion of Thmuis (c.350 A.D.), even then the invocatory epicleses do not focus on a distinct Holy Spirit but rather invoke the holy Word of God to descend and consecrate the elements. ${ }^{35}$ If one were concerned to defend Lactantius's trinitarian orthodoxy (albeit an anachronistic process), it could therefore be argued that as far as he is concerned the complete doctrine of the Spirit is a mysterium arcanum that must be reserved from an uninitiated audience. ${ }^{36}$ The references of Jerome about his letters, however, accord fully with the pneumatology preserved in the DI and suggest that the basic doctrine of the Spirit is fully worked out as far as Lactantius is concerned.

A third, and most likely explanation of the problem is that the 'oddity' of Lactantius' pneumatology has been overemphasized by the theologians of the post-Nicene and post-Constantinopolitan eras (starting with Jerome) and judged by critics of more recent ages as something of an anachronism, when in fact in its own day this kind of pneumatology probably represented, far more honestly, the general level of western articulation about the role of the Holy Spirit than we might be led to believe was operating if we were to think that the speculative trinitarianism of Tertullian, Novatian or Hippolytus ${ }^{37}$ was standard church confessionalism. It is well to remember that even at Nicaea the general level of articulated credal belief in the Holy Spirit can be gauged by one rather bald article. ${ }^{38}$ In regard to formulating a pneumatological doctrine, then, it is undoubtedly the case, as Grillmeier says, that 'the problems which Lactantius finds are no greater than those of his other contemporaries'. The obscurity of the Spirit Christology which he preserves, far from isolating Lactantius from the mainstream of Christian tradition, witnesses that he has remained faithful to the most primitive and archaic tradition, one reflecting the very obscurities of the New Testament experience itself. ${ }^{40}$ Lactantius, therefore, presents an extremely important background to the pneumatological debate that really began in earnest in the last half of the fourth century; and at one and the same time demonstrates the need for that debate.

$35 \mathrm{~N}$. Clarke, ibid., pp.274-5. It is interesting to recall that the most advanced statements of Athanasius himself on the distinct hypostasis of the Holy Spirit are drawn from him in his communication with this bishop Serapion of Thmuis.

36 DI VI, 26.9: abscondi enim tegique mysterium quam fidelissime oportet, maxime a nobis, qui nomen fidei gerimus.

37 The monistic theology of Callistus was probably the stronger tradition, and it is manifested in the Sardican creed as late as 343.

38 Kai eis to Pneuma to hagion.

39 A. Grillmeier, Christ in Christian Tradition, vol.1 (E.T. London, 1975), p.201.

40 Especially the scriptural identification of Christ and God's spirit: e.g. Mk 2:8; Rom 1:3-4; 1 Tim $3: 16$; Heb $9: 14 ; 1$ Pet 3:18-20. 